\title{
Effect of ambient storage on the quality characteristics of aerobically packaged fish curls incorporated with different flours
}

\author{
Waseem Hussain Raja', Sunil Kumar ${ }^{2}$, Zuhaib Fayaz Bhat ${ }^{2 *}$ and Pavan Kumar ${ }^{3}$
}

\begin{abstract}
The present study was conducted to evaluate the effect of ambient storage on the quality attributes of aerobically packaged fish curls incorporated with optimum levels of different flours. The curls were developed by extrusion technology using fish meat (Catla catla). The fish curls containing optimum levels of different flours viz. 20 percent corn flour, 10 percent black gram flour and 10 percent peanut flour were compared with the control snacks containing 30 percent rice flour and assessed for storage quality and shelf life at ambient temperature. The curls were aerobically packaged in LDPE (low density polyethylene) pouches and evaluated for various physicochemical, microbiological and sensory parameters. Mean values of $\mathrm{pH}$ of all the curls showed significantly $(\mathrm{p}<0.05)$ decreasing trend with increasing days of storage $(6.34 \pm 0.01$ on day 0 and $5.90 \pm 0.005$ on day 28 for control samples, $6.41 \pm 0.009$ on day 0 and $6.11 \pm 0.02$ on day 28 for corn flour incorporated samples, $6.36 \pm 0.01$ on day 0 and $6.14 \pm 0.01$ on day 28 for black gram flour incorporated samples, $6.57 \pm 0.007$ on day 0 and $6.34 \pm 0.01$ on day 28 for peanut flour incorporated samples). TBARS (mg malonaldehyde/kg), total plate count (log cfu/g) and yeast and mould count (log cfu/g) for the control as well as treatment samples showed significantly $(p<0.05)$ increasing trend with storage. Coliform counts (log cfu/g) were not detected until day 28 in all the products. The mean scores of sensory parameters i.e. appearance and colour, flavor, crispiness, texture and overall acceptability for control as well as treatment samples showed significantly $(p<0.05)$ decreasing trend with storage period. The decrease was significantly $(p<0.05)$ highest on $21^{\text {st }}$ and $28^{\text {th }}$ day of storage. The mean values for all the quality and storage parameters up to the day 21 of the storage were within the acceptable limits. Thus, based on various physicochemical and sensory parameters, the curls incorporated with optimum level of different flours were acceptable up to 21 days of ambient storage within the LDPE pouches.
\end{abstract}

Keywords: Snacks; Curls; Fish; Flours; Ambient storage; Physicochemical parameters; Sensory attributes

\section{Introduction}

Snacking can be defined as problem free consumption of easy to handle, miniature portioned, hot or cold products in solid or liquid form which need little or no preparation and are intended to satisfy the occasional pangs of hunger (Kumar et al. 2012). Snack food is one of the fastest growing segments of the food industry. Over the decades the consumption of snack food has increased significantly (Thakur and Saxena 2000) and has become integral part

\footnotetext{
* Correspondence: zuhaibbhat@yahoo.co.in

${ }^{2}$ Division of Livestock Products Technology, Faculty of Veterinary Sciences and Animal Husbandry, Sher-e-Kashmir University of Agricultural Sciences and Technology of Jammu, R S Pura, Jammu, Jammu and Kashmir 181102, India

Full list of author information is available at the end of the article
}

of the diet of the world's population due to several reasons like rapid urbanization, changing life style, increase in number of nuclear families and working women, media penetration, and higher disposable incomes. It is the food of choice for school going children, adolescent girls and high mobility groups. The market of snack food industry including semi-processed/cooked and ready to eat foods was around Rs 82.9 billion in 2004 to 2005 and is rising rapidly with a growth rate of 20\% (Singh et al. 2011). Basic criteria for snack foods are convenience, manageable portions and satisfaction of short term hunger (Tettweiler 1991).

Snack products include various types of the products such as cookies, biscuits, pies, sticks, breads, curls etc. 
Most of the snacks available in the market are mainly based on cereals which are high in calorie and low in protein content. If they are taken in large quantity, they can suppress the appetite for the main meal. For this reason, snack with high protein and high fiber should be developed as a supplementary diet (Prabhavat et al. 2000). Curls are ready to eat quick snacks with several attractive features including wider consumption base, relatively longer shelf-life, more convenience and good eating quality. Curls, like most of the snacks, are mainly prepared from cereal grains and these cereals based snack products lack some essential amino acids like tryptophan, threonine and lysine (Kumar et al. 2012). However, protein content and nutritional value of curls can be increased by the addition of high quality protein sources such as fish, legumes and corn. Thus, the incorporation of fish meat along with legumes and corn in the curls is a good alteration in its nutritional value.

Meat based snacks are important snack foods available in the world market particularly in south-east Asia. Fish based snack foods which are commonly known as fishcrackers are popularly consumed in such countries (Suknark et al. 1998). Fish-crackers are traditionally produced by gelatinization of starch in dough made from flour and fish which is shaped, steamed, cooled, sliced, dried, and packaged for sale in polyethylene bags (Siaw et al. 1985). The chemical composition of the fish is valuable in developing high protein snack foods, while ensuring the finest quality flavor, colour, odour, texture. Many of the snacks particularly meat based are produced by extrusion technology. Extrusion is the art or process of shaping by forcing through the die. It's used for various processes like cooking, expansion, texture alteration, mixing and utilization of various ingredients. By extrusion technology cereals, tubers, and their derivatives can be transformed into snack foods and deboned meat can be firmly compressed and reshaped into sticks and links. Historically extrusion cooking of $19^{\text {th }}$ century was used to shape sausage products. Extrusion technology has been widely used for the manufacture of meat and flour based snacks by blending meat with various non-meat products like flours (Prinyawinatkul et al. 2007; Shaviklo et al. 2011).

Fish has received increased attention as a potential source of animal protein and essential nutrients for human diets. It is a good source of essential amino acids, fat-soluble vitamins and several polyunsaturated fatty acids such as linoleic acid, eicosapentaenoic acid (EPA) and docosahexaenoic acid (DHA). Thus, fish based curls can prove to be valuable items to the consumer as a source of essential amino acids and other nutrients. Use of fish meat in the development of curls will open novel opportunity for profitable utilization of fish and improve the nutritional aspect of people as well as prosperity of fish industry. Fish meat based snack food is rarely available in most of the markets of India and information on fish curls is more or less non-existent in literature. Furthermore, rapid expansion of fast food market has increased the development of meat products and warrants immediate attention regarding the development of novel meat products like fish curls. Use of fish may also reduce the cost of meat products since the rates of fish in most of the Indian markets, by and large, are lower than other meats.

Legumes are good source of protein and provide energy, protein, minerals, vitamins and dietary fiber required for human health. Inclusion of legumes in the diet has many physiological effects in controlling and preventing various metabolic diseases such as coronary heart disease and colon cancer (Tharanathan and Mahadevamma 2003). Legume flours have widely been used as extenders in meat products in order to reduce the cost of production and improving the nutrition. Partial replacement of meat by cowpea and peanut (Prinyawiwatkul et al. 1997), cowpea, black bean and green gram (Bhat et al. 2011, 2013a), corn flour (Serdarouglu and Degirmencioglu 2004) and black gram (Modi et al. 2003) have been successfully reported. The use of certain legume proteins such as peanut flour and black gram in the formulation of fish curls would improve the nutritional characteristics and may provide superior functional properties to the product.

The present study was aimed at developing the curls using fish meat and protein rich flours using extrusion technology and further evaluating the shelf life of the developed products. Prospects of further developing certain novel meat products like curls by using fish meat and by extending the same with certain flours could find increasing popularity in food service industry particularly at fast food outlets. Thus, the present study was envisaged to evaluate the effect of ambient storage on the quality characteristics of fish curls incorporated with optimum levels of different flours.

\section{Material and methods}

\section{Fish meat}

Fish (Catla catla, Indian major carp) were purchased from local market of Jammu. The body scales were removed and eviscerated. Deboning of dressed fish was done manually. The lean meat was packed in polythene bags and frozen at $-18 \pm 2^{\circ} \mathrm{C}$ until use.

\section{Condiment mixture}

Condiments used were onion, garlic and ginger. The external covering of all were peeled off and cut into pieces. The cut pieces were weighed in a ratio of 3:2:1 and ground in a mixer to the consistency of fine paste. 


\section{Spice mixture}

The spice mix formula used for preparation of the fish curls contained anise (Pimpinalla anisum, soanf-13\%), bay leaves (Laurus nobilis, tej patta-2\%), black pepper (Piper nigrum, kali mirch-5\%), green cardamom (Elettaria cardamomum, choti elaichi-5\%), cinnamon (Cinnamomum zeylanicum, dalchini-6\%), cloves (Syzygium aromaticum, laung-2\%), dry fenugreek powder (Foenum-graecum, meathi-6\%), coriander (Coriandrum sativum, dhania-20\%), cumin seed (Cuminum cyminum, jeera-12\%), mace (Myristica fragrans, javitri-2\%), nutmeg (Myristica fragrans, jaiphal-2\%), red chilli (Capsicum frutescens, lal mirch-12\%), black cardamom (Amomum subulatum, badi elaichi-5\%), mint leaves (Lamiaceae, pudina-3\%) and dry ginger powder (Zingiber officinale, saunth-5\%). The spices were purchased from local market. After removal of extraneous matter, all spices were dried in an oven at $50^{\circ} \mathrm{C}$ for overnight and then ground in grinder to powder. The coarse particles were removed using a sieve (100 mesh) and the fine powdered spices were mixed in required proportion to obtain spice mixture for fish curls. The spice mixture was stored in plastic airtight container for subsequent use.

\section{Fat}

Refined cottonseed oil of brand name 'Ginni' (Amrit Banaspati Company Limited, India) was purchased from local market and used in emulsion preparation as well as for deep fat frying of the curls. It approximately contained 900 k.cal of energy, $0 \mathrm{~g}$ of carbohydrate, $0 \mathrm{~g}$ of proteins, $0 \mathrm{~g}$ of cholesterol, $24 \mathrm{~g}$ of saturated fatty acids, $54 \mathrm{~g}$ of mono-unsaturated fatty acids and $0 \mathrm{~g}$ of trans-fatty acids per 100 grams.

The fish curls were prepared by incorporating two fat levels viz. 0 percent and 5 percent in the emulsion. The various sensory attributes viz. colour and appearance, flavour, crispness, texture and overall acceptability were significantly $(\mathrm{p}<0.05)$ higher in the curls made from formulation containing 0 percent refined cottonseed oil. Thus 0 percent oil was optimized as best for the emulsion preparation.

\section{Flours}

Refined wheat flour, rice flour and defatted corn flour were brought from local market. Peanuts and black gram were purchased from local market and processed to flour in the division of Livestock Products Technology, SKUAST of Jammu.

On the basis of preliminary trials, incorporation of 30 percent level of rice flour was optimized as best for the development of control fish curls. Rice flour was incorporated at 25 and 30 percent level in the basic formulation of fish curls. The mean values of sensory scores viz. colour and appearance, crispiness, texture and overall acceptability at 30 percent incorporation of rice flour were significantly $(\mathrm{p}<0.05)$ higher as compared to 25 percent rice flour.

The three flours viz. corn flour (approximately containing moisture $2.7 \%$, crude protein $0.40 \%$, crude fat $0 \%$, carbohydrates $96.7 \%$ ), black gram flour (approximately moisture $10 \%$, crude protein $22 \%$, crude fat $6 \%$, carbohydrates $57 \%$ ) and peanut flour (moisture $6 \%$, crude protein $27 \%$, crude fat $47 \%$, carbohydrates $19 \%$ ) were incorporated at three different levels viz. 10, 20 and 30 percent to replace corresponding amounts of rice flour in the formulation of fish curls. Based on various physicochemical and sensory parameters, incorporation of 20 percent corn flour, 10 percent black gram flour and 10 percent peanut flour were optimized as best.

\section{Preparation of emulsion}

Several preliminary trials were conducted to standardize the formulation for preparation of emulsion for fish curls as indicated in Table 1. Figure 1 shows the flow diagram for the preparation of fish curls. Fish meat was cut into smaller chunks and minced in a Sirman mincer (MOD-TC 32 R10 U.P. INOX, Marsango, Italy) with $6 \mathrm{~mm}$ plate. Meat emulsion for fish was prepared in Sirman Bowl Chopper [MOD C 15 2.8G 4.0 HP, Marsango, Italy]. Minced meat was chopped with all the curing ingredients (sodium bicarbonate, sodium nitrite, sodium tripolyphosphate (STPP), common salt) for 1.5 minute. Water in the form of crushed ice was added and blending continued for 1 minute. This was followed by addition of spice mixture, condiments and other ingredients and again mixed for 1.5 to 2 minutes to get the desired emulsion. Adequate care was taken to keep the end point temperature below $18^{\circ} \mathrm{C}$ by preparing the

Table 1 Formulation of fish curls with rice, corn, black gram and peanut flour

\begin{tabular}{lcccc}
\hline Ingredients & $\begin{array}{c}\text { RF } \\
\mathbf{( 3 0} \%)\end{array}$ & $\begin{array}{c}\text { CF } \\
\mathbf{( 2 0} \%)\end{array}$ & $\begin{array}{c}\text { BGF } \\
\mathbf{( 1 0 \% )}\end{array}$ & $\begin{array}{c}\text { PNF } \\
\mathbf{( 1 0 \% )}\end{array}$ \\
\hline Fish meat & 47 & 47 & 47 & 47 \\
Added water & 10 & 10 & 10 & 10 \\
Condiment mixture & 2.7 & 2.7 & 2.7 & 2.7 \\
Rice flour & 30 & 10 & 20 & 20 \\
Corn flour & - & 20 & - & - \\
Black gram flour & - & - & 10 & - \\
Peanut flour & - & - & - & 10 \\
Refined wheat flour & 5 & 5 & 5 & 5 \\
Spice mixture & 2 & 2 & 2 & 2 \\
Table salt & 2.5 & 2.5 & 2.5 & 2.5 \\
Sodium tripolyphosphate & 0.3 & 0.3 & 0.3 & 0.3 \\
Sodium nitrite & $150 \mathrm{ppm}$ & $150 \mathrm{ppm}$ & $150 \mathrm{ppm}$ & $150 \mathrm{ppm}$ \\
Sodium bicarbonate & 0.5 & 0.5 & 0.5 & 0.5 \\
\hline
\end{tabular}

$\mathrm{RC}=$ Rice flour (control), $\mathrm{CF}=$ Corn flour, $\mathrm{BGF}=$ Black gram flour, $\mathrm{PNF}=$ peanut flour. 


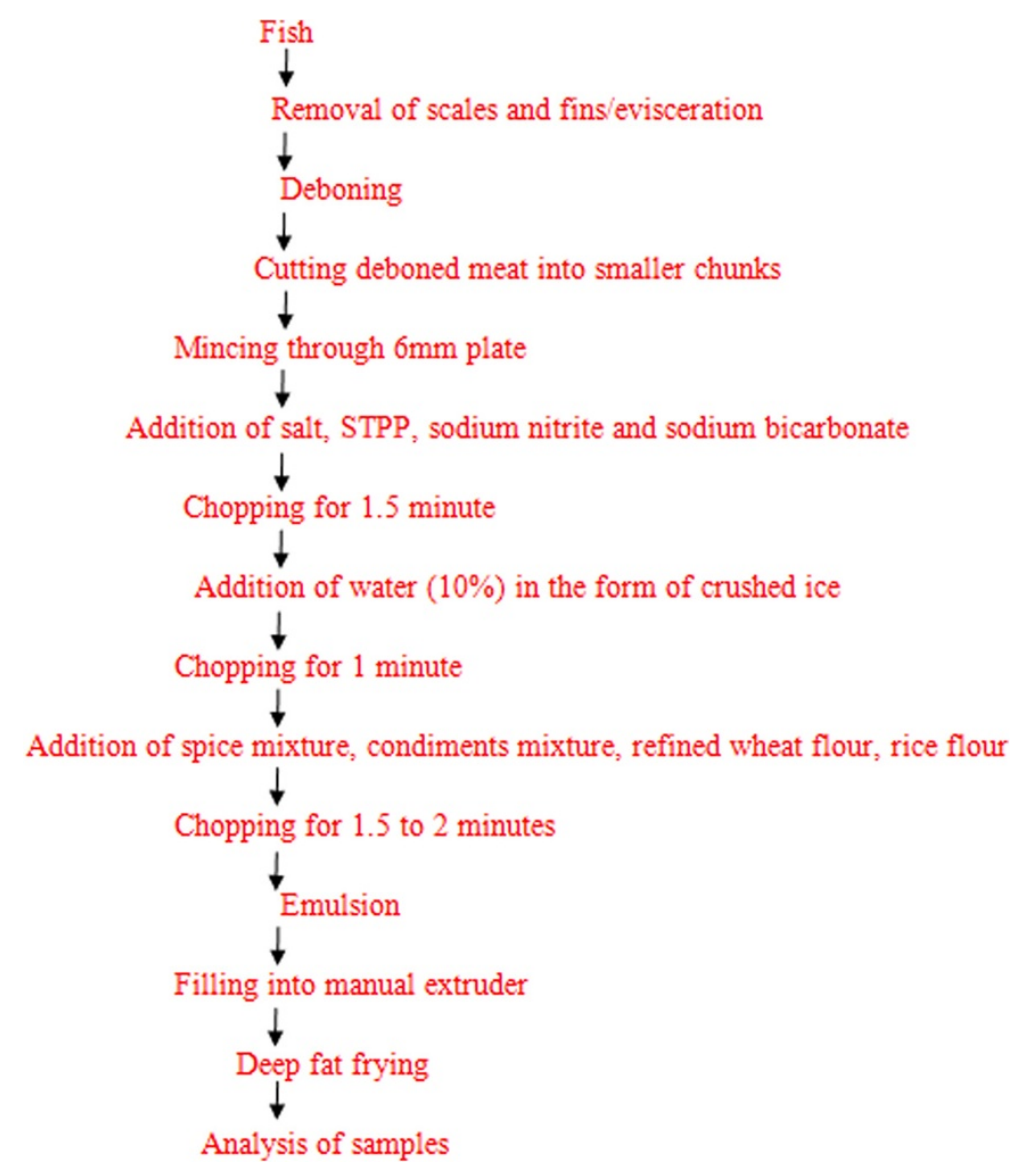

Figure 1 Flow diagram for the preparation of fish curls.

emulsion in cool hours of morning, by addition of meat and other ingredients in chilled/partially thawed form and by addition of crushed ice.

Deep fat frying method was employed for cooking of curls. Emulsion obtained was filled into the manual extruder and curls obtained from the extruder were directly deep fat fried in the refined cottonseed oil. The products were cooked at different time-temperature combinations and based on mean values of various sensory parameters fish curls cooked at $180 \pm 5^{\circ} \mathrm{C}$ for $3 \pm 1$ minutes were optimized as best. The temperature of the oil was measured by a digital thermometer.

\section{Analytical procedures}

The $\mathrm{pH}$ of cooked fish curls was determined by the method of Keller et al. (1974) using a digital meter (Systronics Digital pH Meter 803, serial No. 603). Thiobarbituric acid reacting substances value of fish curls during storage was determined using the method described by Witte et al. (1970). Microbiological profile viz. total plate count, coliform count and yeast and mold count were determined by methods described by APHA
(1984). Readymade media (Hi-Media) were used for the analysis.

\section{Sensory evaluation}

The sensory evaluation of the products was carried for various attributes namely colour and appearance, flavour, crispiness, texture and overall acceptability by a panel of seven trained members composed of scientists and research scholars of the Division based on a 8-point hedonic scale, wherein 8 denoted "extremely desirable" and 1 denoted "extremely undesirable" (Seman et al. 1987). Panelists were seated in a room free of noise and odours and suitably illuminated. Coded samples for sensory evaluation were prepared and served warm to panelists. Water was provided for oral rinsing between the samples.

\section{Statistical analysis}

Means and standard errors were calculated for different parameters. Factorial design of experiment was fallowed. Analysis of variance was performed as per Snedecor and Cochran (1994). In significant effects, least significant differences were calculated at appropriate level of significance for a pair wise comparison of treatment means. 


\section{Results and discussion}

\section{Chemical measurements}

The mean values of chemical measurements namely $\mathrm{pH}$ and thiobarbituric acid reacting substances value of aerobically packaged fish curls containing different flours are presented in Table 2 .

$\mathrm{pH}$

The effect of storage was obvious as the $\mathrm{pH}$ of fish curls followed a decreasing trend at progressive storage intervals. There was a significant decrease $(\mathrm{p}<0.05)$ in $\mathrm{pH}$ of almost all variants except the curls made with 10 percent black gram in which the decrease was nonsignificant $(\mathrm{p}>0.05)$ on day 7 and 14 and also on day 21 and 28. The decrease in $\mathrm{pH}$ might be attributed to the availability of more readily utilizable carbohydrate molecules by the microbes and thereby formation of lactic acid. It is an established fact that a decrease in $\mathrm{pH}$ is usually attributed to the metabolic activity of bacteria (Jay 1996). The decrease in $\mathrm{pH}$ in meat products also depended on the presence of fermentable carbohydrates (Borch et al. 1996). Singh et al. (2011) reported gradual decrease in the $\mathrm{pH}$ of chicken snacks stored in laminated pouches at ambient temperature. Between the treatments, the curls made with the incorporation of 10 percent peanut flour had significantly $(\mathrm{p}<0.05)$ higher $\mathrm{pH}$ at all intervals of storage. This could be possibly due to more basic nature of peanut flour than rest of the flours used in the formulation. Chang et al. (2010) reported a similar decrease in $\mathrm{pH}$ during storage in sausages treated with carrot and onion. García et al. (2002) also observed a similar decrease in $\mathrm{pH}$ of low fat dry fermented sausages prepared with cereals and fruit fibers. Incze (1992) reported that decrease in the $\mathrm{pH}$ values might be due to significant $(\mathrm{P}<0.05)$ increase in microbial count during storage period producing lactic acid by breakdown of carbohydrates. Murguerza et al. (2002) also reported a progressive decrease in $\mathrm{pH}$ of dry fermented sausages.

\section{Thiobarbituric acid reacting substances value (mg malonaldehyde/Kg)}

Thiobarbituric acid reacting substances (TBARS) value followed a significantly $(\mathrm{p}<0.05)$ increasing trend from day 0 to 28 in case of both control and treated curls. TBARS value of all products increased significantly $(p<0.05)$ at all intervals of storage. The increase in TBARS values on storage might be attributed to oxygen permeability of packaging material (Brewer et al. 1992) that led to lipid oxidation. Ratanatriwong et al. (2011), Singh et al. (2011) and Park et al. (1993) reported gradual increase in the TBARS values in fish, beef and chicken snacks respectively stored at ambient temperature. Chidanandaiah et al. (2009), Modi et al. (2003), Kumar and Tanwar (2011), Sudheer et al. (2011), Bhat and Pathak (2011) and Bhat et al. (2010) also reported a similar increase in TBARS values upon storage of different meat products. Between the treatments the TBARS value of corn flour curls were significantly lower as compared to other treatments at all intervals of storage. This might be possibly due to low fat content of corn flour used in the preparation of curls. However, in the present study TBARS values were much lower than threshold value of $2 \mathrm{mg} / \mathrm{kg}$ (Greene and Cumuze 1982) even by day 28. Similar findings were reported by Bhat et al. (2013a) and Bhat et al. (2011) in chicken seekh kababs extended with different non-meat proteins. Similar results were observed by Das et al. (2013) in chicken nuggets containing fermented bamboo shoot and Banerjee et al. (2012) in goat meat nuggets containing broccoli powder extract.

Table 2 Effect of ambient storage on the chemical measurements of aerobically packaged fish curls incorporated with rice, corn, black gram and peanut flour (Mean $\pm S E$ )

\begin{tabular}{|c|c|c|c|c|c|}
\hline \multirow[t]{2}{*}{ Treatment } & \multicolumn{5}{|c|}{ Storage period (days) } \\
\hline & 0 & 7 & 14 & 21 & 28 \\
\hline \multicolumn{6}{|c|}{$\mathrm{pH}$} \\
\hline RF (30\%) & $6.34 \pm 0.01^{\mathrm{Ae}}$ & $6.19 \pm 0.007^{\mathrm{Ad}}$ & $6.14 \pm 0.01^{\mathrm{Ac}}$ & $6.07 \pm 0.006^{\mathrm{Ab}}$ & $5.90 \pm 0.005^{\mathrm{Aa}}$ \\
\hline CF (20\%) & $6.41 \pm 0.009^{B e}$ & $6.34 \pm 0.007^{\mathrm{Bd}}$ & $6.28 \pm 0.006^{\mathrm{BC}}$ & $6.23 \pm 0.006^{\mathrm{Bb}}$ & $6.11 \pm 0.02^{\mathrm{Ba}}$ \\
\hline BGF (10\%) & $6.36 \pm 0.01^{\mathrm{Ac}}$ & $6.27 \pm 0.006^{\mathrm{Cb}}$ & $6.25 \pm 0.006^{\mathrm{Cb}}$ & $6.16 \pm 0.01^{\mathrm{Ca}}$ & $6.14 \pm 0.01^{\mathrm{Ca}}$ \\
\hline PNF (10\%) & $6.57 \pm 0.007^{\mathrm{Ce}}$ & $6.50 \pm 0.005^{\mathrm{Dd}}$ & $6.44 \pm 0.008^{D c}$ & $6.39 \pm 0.009^{\mathrm{Db}}$ & $6.34 \pm 0.01^{\mathrm{Da}}$ \\
\hline \multicolumn{6}{|c|}{ TBARS (mg malonaldehyde/Kg.) } \\
\hline RF (30\%) & $0.38 \pm 0.006^{\mathrm{Ca}}$ & $0.46 \pm 0.008^{\mathrm{Bb}}$ & $0.65 \pm 0.007^{\mathrm{Cc}}$ & $0.79 \pm 0.02^{\mathrm{Ad}}$ & $1.28 \pm 0.01^{\mathrm{BCe}}$ \\
\hline CF $(20 \%)$ & $0.30 \pm 0.01^{\mathrm{Aa}}$ & $0.43 \pm 0.01^{\mathrm{Ab}}$ & $0.54 \pm 0.01^{\mathrm{Ac}}$ & $0.64 \pm 0.008^{\mathrm{Ad}}$ & $1.18 \pm 0.02^{\mathrm{Ae}}$ \\
\hline BGF (10\%) & $0.35 \pm 0.01^{\mathrm{Ba}}$ & $0.54 \pm 0.007^{\mathrm{cb}}$ & $0.61 \pm 0.009^{B C}$ & $0.73 \pm 0.009^{\mathrm{Bd}}$ & $1.26 \pm 0.02^{\mathrm{Be}}$ \\
\hline PNF (10\%) & $0.44 \pm 0.006^{\mathrm{Da}}$ & $0.56 \pm 0.01^{\mathrm{Db}}$ & $0.70 \pm 0.010^{\mathrm{Dc}}$ & $0.78 \pm .008^{\mathrm{Cd}}$ & $1.31 \pm 0.11^{\mathrm{Ce}}$ \\
\hline
\end{tabular}

${ }^{*}$ Mean \pm SE with different superscripts in row (lower case alphabet) and column (Upper case alphabet) differ significantly $(\mathrm{p}<0.05), \mathrm{n}=6 \mathrm{for}$ each treatment, $\mathrm{RC}=$ Rice flour (control), $\mathrm{CF}=$ Corn flour, $\mathrm{BGF}=$ Black gram flour, $\mathrm{PNF}=$ peanut flour. 


\section{Microbiological characters}

The mean values of various microbiological characteristics of aerobically packaged fish curls containing different flours are presented in Table 3.

\section{Total plate count (log cfu/g)}

Total plate count $(\mathrm{TPC})$ followed a significantly $(\mathrm{p}<0.05)$ increasing trend as the storage days progressed in control as well as treated curls. However, total plate count showed a non-significant $(p>0.05)$ difference among different treatments at all the intervals of storage. Singh et al. (2011) also reported an increase in TPC at each storage interval in meat snacks. Similar findings were reported by Kumar et al. (2007) in chicken meat patties who also reported an increase in total plate count at each storage interval both in control and treatment samples. This is also in agreement with the findings of Chidanandaiah et al. (2009), Kumar and Tanwar (2011), Bhat et al. (2010), Bath and Pathak (2011), Bhat et al. (2013a) and Bhat et al. (2013b) who also reported the similar results in meat patties, chicken nuggets, chevon Harissa, mutton Harrisa, chicken seekh kababs and chicken meat balls respectively.

The higher TPC observed in fish curls in the present study might be probably due to easy availability of carbohydrate-rich starch in the fortified snack product to favor microbial growth. However, in the present study TPC count of control and treatment curls did not exceed the permissible level of microbial standards $\left(\log 10^{6} \mathrm{cfu}\right.$ $\mathrm{g}^{-1}$ of sample) in cooked meat products as reported by Jay (1996) even on $28^{\text {th }}$ day of storage.

\section{Coliform count (log cfu/g)}

The coliforms were not detected in all treatments and control up to $21^{\text {st }}$ day of storage. This could be due to the destruction of these bacteria during cooking at $180 \pm 5^{\circ} \mathrm{C}$, far above their thermal death point of $57^{\circ} \mathrm{C}$; hygienic practices followed during the preparation and packaging of curls. However, the counts appeared in all treatments on day 28. The count in control and treatments were comparable to each other. Appearance of coliforms later onwards could be because of contamination. Singh et al. (2011) have reported similar findings in chicken snacks at ambient temperature. Similar results were reported by Kumar and Sharma (2004) in pork patties, Kandeepan et al. (2010) in buffalo meat keema, Bhat et al. (2010) in chevon Harrisa, Bhat and Pathak (2011) in mutton Harrisa, Bhat et al. (2013a) in chicken seekh kababs and Bhat et al. (2013b) in chicken meat balls who also reported zero count of coliform for the products heated to such a high temperature.

\section{Yeast and mould count (log cfu/g)}

The yeast and mould counts were not detected up to $14^{\text {th }}$ day of storage. However they appeared on day 21 onwards and followed a significantly $(\mathrm{p}<0.05)$ increasing trend in all the treatments. The detection of yeast and mold counts on day $21^{\text {st }}$ and $28^{\text {th }}$ possibly could be due to post processing contamination. Singh et al. (2011) reported that yeast and mold appeared during the last day of storage of chicken snacks due to the availability of nutrients in meat. Among the treatments the counts

Table 3 Effect of ambient storage on the microbiological characteristics of aerobically packaged fish curls incorporated with rice, corn, black gram and peanut flour (Mean $\pm \mathrm{SE})^{*}$

\begin{tabular}{|c|c|c|c|c|c|}
\hline \multirow[t]{2}{*}{ Treatments } & \multicolumn{5}{|c|}{ Storage period (days) } \\
\hline & 0 & 7 & 14 & 21 & 28 \\
\hline \multicolumn{6}{|c|}{ Total plate count (log cfu/g) } \\
\hline RF (30\%) & $2.24 \pm 0.05^{\mathrm{e}}$ & $2.79 \pm 0.31^{d}$ & $3.35 \pm 0.04^{c}$ & $4.73 \pm 0.04^{b}$ & $5.46 \pm 0.04^{a}$ \\
\hline CF (20\%) & $2.21 \pm 0.29^{e}$ & $2.50 \pm 0.33^{d}$ & $3.42 \pm 0.06^{c}$ & $4.58 \pm 0.03^{b}$ & $5.36 \pm 0.03^{\mathrm{a}}$ \\
\hline BGF (10\%) & $2.30 \pm 0.02^{\mathrm{e}}$ & $2.77 \pm 0.23^{d}$ & $3.43 \pm 0.04^{c}$ & $4.70 \pm 0.05^{b}$ & $5.51 \pm 0.03^{\mathrm{a}}$ \\
\hline PNF (10\%) & $2.29 \pm 0.01^{\mathrm{e}}$ & $2.89 \pm 0.03^{d}$ & $3.47 \pm 0.05^{c}$ & $4.66 \pm 0.04^{b}$ & $5.34 \pm 0.03^{\mathrm{a}}$ \\
\hline \multicolumn{6}{|c|}{ Coliform count (log cfu/g) } \\
\hline RF (30\%) & ND & ND & ND & ND & $2.56 \pm 0.05$ \\
\hline CF $(20 \%)$ & ND & ND & ND & ND & $2.45 \pm 0.01$ \\
\hline BGF (10\%) & ND & ND & ND & ND & $2.62 \pm 0.04$ \\
\hline PNF (10\%) & ND & ND & ND & ND & $2.62 \pm 0.07$ \\
\hline \multicolumn{6}{|c|}{ Yeast and mould count (log cfu/g) } \\
\hline RF (30\%) & ND & ND & ND & $2.48 \pm 0.01^{\mathrm{Ba}}$ & $3.53 \pm 0.01^{\mathrm{Bb}}$ \\
\hline CF (20\%) & ND & ND & ND & $2.32 \pm 0.02^{\mathrm{Aa}}$ & $3.46 \pm 0.01^{\mathrm{Ab}}$ \\
\hline BGF (10\%) & ND & ND & ND & $2.70 \pm 0.05^{\mathrm{Ca}}$ & $3.78 \pm 0.01^{\mathrm{Db}}$ \\
\hline PNF (10\%) & ND & ND & ND & $2.56 \pm 0.01^{\mathrm{Ba}}$ & $3.63 \pm 0.02^{\mathrm{Cb}}$ \\
\hline
\end{tabular}

*Mean \pm SE with different superscripts in a row (lower case alphabet) and column (Upper case alphabet) differ significantly $(p<0.05), \mathrm{n}=6$ for each treatment, $\mathrm{RC}=$ Rice flour (control), $\mathrm{CF}=$ Corn flour, $\mathrm{BGF}=$ Black gram flour, $\mathrm{PNF}=$ peanut flour, $\mathrm{ND}=$ Not detected. 
were significantly $(\mathrm{p}<0.05)$ higher for snacks containing black gram flour both on $21^{\text {st }}$ and $28^{\text {th }}$ day of storage. Das et al. (2013) also reported similar results in chicken nuggets.

\section{Sensory parameters}

Mean sensory scores of aerobically packaged fish curls containing different flours during ambient storage are presented in Table 4. Figure 2 shows the fish curls incorporated with optimum levels of different flours.

\section{Colour and appearance}

The colour and appearance scores followed a linear decreasing trend as the storage days progressed. This decrease was significantly $(\mathrm{p}<0.05)$ highest on $21^{\text {st }}$ and $28^{\text {th }}$ day of storage. The scores showed a non-significant ( $p>0.05$ ) decrease up to day $14^{\text {th }}$ in all the products. A similar decrease in appearance and colour scores of chicken and fish snacks with increase in storage period was also reported by Singh et al. (2011) and Ratanatriwong et al. (2011) respectively. Similar findings were also reported by Kumar and Sharma (2004) in chicken patties, Kilinc (2009) in anchovy patties, Chidanandaiah et al. (2009) in buffalo patties, Bhat et al. (2010) in chevon Harrisa, Bhat et al. (2013a) in chicken seekh kababs and Bhat et al. (2013b) in chicken meat balls respectively.

Among the treatments the colour and appearance scores were comparable $(\mathrm{p}>0.05)$ on $28^{\text {th }}$ day of storage. However on day $0,7,14$ and 21 the scores among the treatments were significantly $(\mathrm{p}<0.05)$ higher in the curls incorporated with black gram and peanut flour in the formulation as compared to control and corn flour incorporated curls. This could be possibly attributed to the suitable golden colour imparting property of these flours.

Table 4 Effect of ambient storage on sensory attributes of aerobically packaged fish curls incorporated with rice, corn, black gram and peanut flour (Mean $\pm \mathrm{SE})^{*}$

\begin{tabular}{|c|c|c|c|c|c|}
\hline \multirow[t]{2}{*}{ Treatments } & \multicolumn{5}{|c|}{ Storage period (days) } \\
\hline & 0 & 7 & 14 & 21 & 28 \\
\hline \multicolumn{6}{|c|}{ Colour and appearance } \\
\hline RF (30\%) & $6.28 \pm 0.11^{\mathrm{Ac}}$ & $6.21 \pm 0.11^{\mathrm{Ac}}$ & $6.02 \pm 0.08^{\mathrm{Ac}}$ & $5.78 \pm 0.12^{\mathrm{Ab}}$ & $5.26 \pm 0.17^{\mathrm{a}}$ \\
\hline CF (20\%) & $6.88 \pm 0.06^{B C}$ & $6.78 \pm 0.08^{B C}$ & $6.57 \pm 0.10^{\mathrm{AC}}$ & $6.28 \pm 0.12^{\mathrm{Ab}}$ & $5.21 \pm 0.16^{\mathrm{a}}$ \\
\hline BGF (10\%) & $7.45 \pm 0.07^{C c}$ & $7.33 \pm 0.07^{\mathrm{Cc}}$ & $6.84 \pm 0.10^{B C}$ & $6.73 \pm 0.13^{\mathrm{Bb}}$ & $5.30 \pm 0.20^{a}$ \\
\hline PNF (10\%) & $7.50 \pm 0.09^{C c}$ & $7.42 \pm 0.09^{\complement c}$ & $7.23 \pm 0.05^{B C}$ & $6.83 \pm 0.07^{\mathrm{Bb}}$ & $5.45 \pm 0.10_{a}$ \\
\hline \multicolumn{6}{|c|}{ Flavour } \\
\hline RF (30\%) & $6.42 \pm 0.11^{\mathrm{Ac}}$ & $6.26 \pm 0.13^{\mathrm{AC}}$ & $6.19 \pm 0.09^{A C}$ & $5.57 \pm 0.11^{\mathrm{Ab}}$ & $4.57 \pm 0.13^{\mathrm{a}}$ \\
\hline CF (20\%) & $6.78 \pm 0.11^{B C}$ & $6.54 \pm 0.10^{\mathrm{AC}}$ & $6.45 \pm 0.09^{\mathrm{Ac}}$ & $5.61 \pm 0.10^{\mathrm{Ab}}$ & $4.76 \pm 0.17^{\mathrm{a}}$ \\
\hline BGF (10\%) & $7.19 \pm 0.08^{\mathrm{Cd}}$ & $6.97 \pm 0.10^{c c d}$ & $6.78 \pm 0.11^{\mathrm{BC}}$ & $5.52 \pm 0.11^{\mathrm{Ab}}$ & $4.30 \pm 0.22^{a}$ \\
\hline PNF (10\%) & $7.23 \pm 0.06^{C c}$ & $7.11 \pm 0.06_{C c}$ & $6.90 \pm 0.07^{B C}$ & $5.92 \pm 0.09^{\mathrm{Bb}}$ & $4.80 \pm 0.17^{a}$ \\
\hline \multicolumn{6}{|c|}{ Crispiness } \\
\hline RF (30\%) & $6.26 \pm 0.13^{\mathrm{Ac}}$ & $6.19 \pm 0.12^{\mathrm{AC}}$ & $5.95 \pm 0.09_{A C}$ & $5.47 \pm 0.012^{b}$ & $4.59 \pm 0.11^{\mathrm{a}}$ \\
\hline CF (20\%) & $7.19 \pm 0.08^{B C}$ & $7.09 \pm 0.09^{B C}$ & $6.51 \pm 0.10_{\mathrm{Bb}}$ & $5.92 \pm 0.14^{b}$ & $4.66 \pm 0.15^{\mathrm{a}}$ \\
\hline BGF (10\%) & $7.04 \pm 0.04_{B d}$ & $6.95 \pm 0.05^{\mathrm{Bd}}$ & $6.58 \pm 0.11_{A C}$ & $5.97 \pm 0.90^{b}$ & $4.76 \pm 0.15^{a}$ \\
\hline PNF (10\%) & $7.16 \pm 0.09_{\mathrm{Bd}}$ & $7.09 \pm 0.05^{\mathrm{Bd}}$ & $6.76 \pm 0.08_{B C}$ & $6.07 \pm 0.11^{b}$ & $4.88 \pm 0.10^{\mathrm{a}}$ \\
\hline \multicolumn{6}{|c|}{ Texture } \\
\hline RF (30\%) & $6.83 \pm 0.12^{B C C}$ & $6.64 \pm 0.12^{\mathrm{AC}}$ & $6.42 \pm 0.11^{\mathrm{Ab}}$ & $6.28 \pm 0.11^{\mathrm{b}}$ & $5.64 \pm 0.11^{a}$ \\
\hline CF $(20 \%)$ & $6.47 \pm 0.09^{A c}$ & $6.40 \pm 0.08^{A b c}$ & $6.30 \pm 0.08^{\mathrm{Abc}}$ & $6.11 \pm 0.11^{b}$ & $5.76 \pm 0.11^{a}$ \\
\hline BGF (10\%) & $7.09 \pm 0.09^{C c}$ & $7.02 \pm 0.08^{B C}$ & $6.78 \pm 0.10^{B C}$ & $6.30 \pm 0.15^{b}$ & $5.64 \pm 0.10^{\mathrm{a}}$ \\
\hline PNF (10\%) & $6.76 \pm 0.10^{\mathrm{ABC}}$ & $6.69 \pm 0.10^{A C}$ & $6.54 \pm 0.10^{\mathrm{ABbc}}$ & $6.33 \pm 0.12^{b}$ & $5.97 \pm 0.11^{\mathrm{a}}$ \\
\hline \multicolumn{6}{|c|}{ Overall acceptability } \\
\hline RF (30\%) & $6.35 \pm 0.10^{A C}$ & $6.26 \pm 0.11^{\mathrm{Ac}}$ & $6.07 \pm 0.10^{A c}$ & $5.69 \pm 0.13^{b}$ & $4.28 \pm 0.14^{a}$ \\
\hline CF $(20 \%)$ & $7.11 \pm 0.08^{B C}$ & $6.97 \pm 0.12^{\mathrm{BC}}$ & $6.64 \pm 0.11^{B C}$ & $5.92 \pm 0.07^{b}$ & $4.59 \pm 0.19^{a}$ \\
\hline BGF (10\%) & $7.26 \pm 0.07^{B C d}$ & $7.14 \pm 0.08^{B C}$ & $6.73 \pm 0.09^{B C}$ & $5.76 \pm 0.16^{b}$ & $4.23 \pm 0.16^{a}$ \\
\hline PNF (10\%) & $7.45 \pm 0.09^{\complement c}$ & $7.26 \pm 0.08^{B c}$ & $6.88 \pm 0.08^{C c}$ & $5.95 \pm 0.11^{b}$ & $4.71 \pm 0.12^{\mathrm{a}}$ \\
\hline
\end{tabular}

${ }^{*}$ Mean \pm SE with different superscripts in a row (lower case alphabet) and column (Upper case alphabet) differ significantly $(p<0.05), n=6$ for each treatment, $\mathrm{RC}=$ Rice flour (control), $\mathrm{CF}=$ Corn flour, $\mathrm{BGF}=$ Black gram flour, $\mathrm{PNF}=$ peanut flour. 


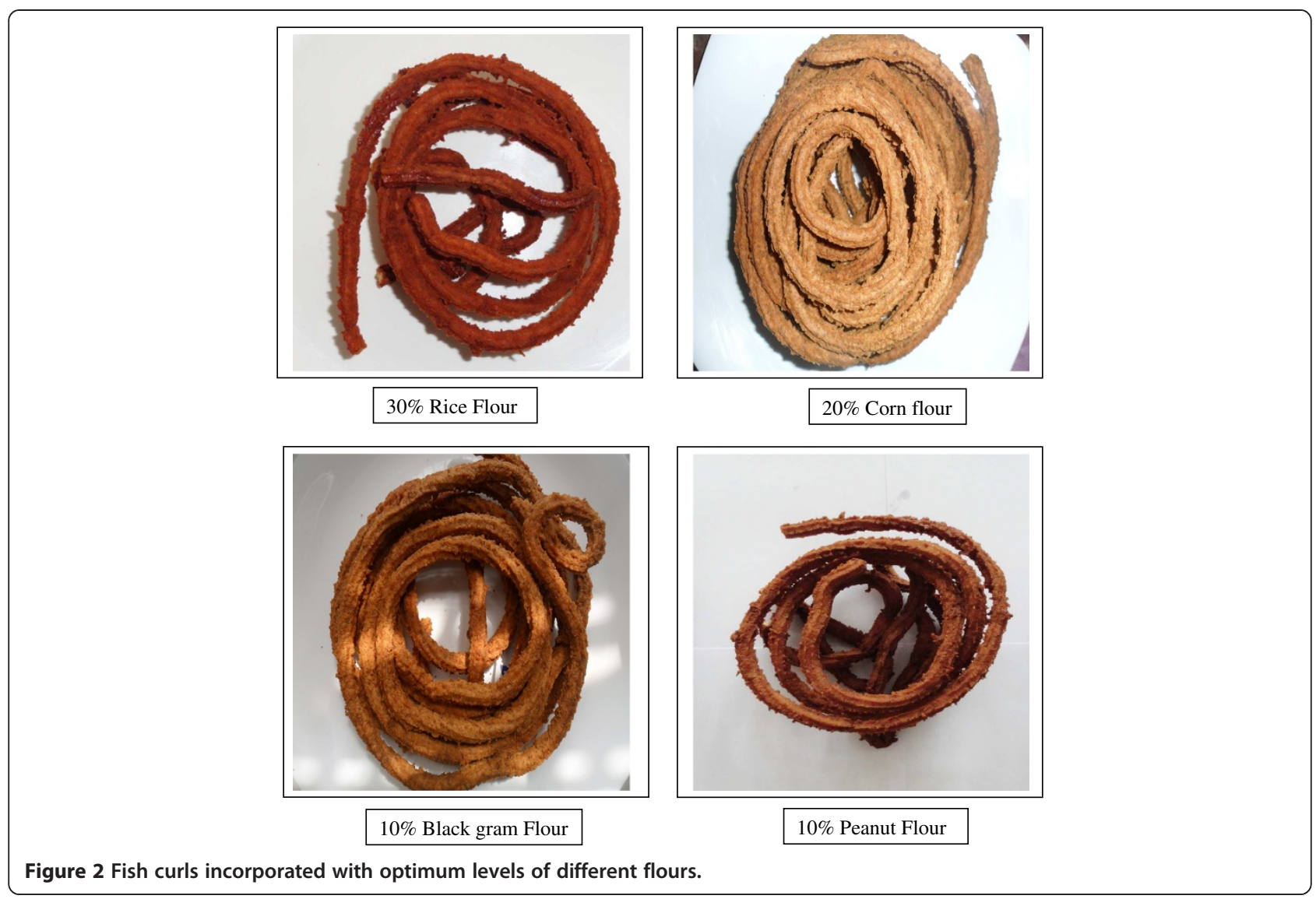

\section{Flavour}

Flavour of the products decreased gradually $(p>0.05)$ as the days of storage progressed and on $28^{\text {th }}$ day of storage the score was significantly $(\mathrm{p}<0.05)$ lowest. The reduction in flavour could be attributed to the increased lipid oxidation, liberation of fatty acids and increased microbial load (Sahoo and Anjaneyulu 1997). A gradual decline of flavour might also be due to the expected loss of volatile flavour components from spices and condiments on storage of meat products. The progressive decrease in flavour could be correlated to increase in TBARS value of meat products (Tarladgis et al. 1960) stored under aerobic conditions. Decline in flavour scores of meat snacks during storage was also reported by Singh et al. (2011). The decrease in flavour and meat flavour scores with the advancement of the storage period might also be due to dilution in meaty flavour. Similar reports have been published by Padda et al. (1989), Kumar and Sharma (2004), Bhat and Pathak (2009), Bhat et al. (2013a) and Bhat et al. (2013b) for various meat products. However, among the treatments the flavour score showed a nonsignificant $(p>0.05)$ difference on $28^{\text {th }}$ day of storage. The flavour score among the treatments was significantly $(\mathrm{p}<0.05)$ higher in the curls incorporated with black gram and peanut flour in the formulation as compared to control and corn flour incorporated curls on 0,7 and $14^{\text {th }}$ day of storage.

\section{Crispiness}

Crispiness decreased gradually as the days of storage progressed and on $28^{\text {th }}$ day of storage the score was significantly $(\mathrm{p}<0.05)$ lowest. The score was non-significant up to $7^{\text {th }}$ day of storage. Crispiness scores might have decreased because of moisture absorption with the increase in storage days. However, among the different treatments the scores showed a significant $(\mathrm{p}<0.05)$ difference on 0 , 7 and $14^{\text {th }}$ day of storage, whereas on $21^{\text {st }}$ and $28^{\text {th }}$ day of storage the scores were comparable $(\mathrm{p}>0.05)$.

\section{Texture}

Texture of the products decreased linearly as the storage progressed and the scores were comparable $(p>0.05)$ up to $14^{\text {th }}$ day of storage in all the treatments. The decrease in scores was significant $(\mathrm{p}<0.05) 21^{\text {th }}$ day onwards. However, among the different treatments the scores showed a non-significant $(\mathrm{p}>0.05)$ difference on $21^{\text {st }}$ and $28^{\text {th }}$ day of storage. Similar observations have also been reported by Kumar and Sharma (2004), Bhat and Pathak (2009), Bhat et al. (2013a) and Bhat et al. (2013b) for various meat products. Kalra et al. (1987) also observed slight 
decrease in the texture scores of snacks packaged in low density polyethylene (LDPE) pouches.

\section{Overall acceptability}

Overall acceptability of control as well as flour incorporated curls decreased linearly as the storage days progressed. The scores showed a non-significant decrease up to $14^{\text {th }}$ day of the storage in almost all the products. However, among the treatments the scores showed a non-significant $(\mathrm{p}>0.05)$ difference on $21^{\text {st }}$ and $28^{\text {th }}$ day of storage. The scores among the treatments showed a significant $(\mathrm{p}<0.05)$ difference on 0,7 and $14^{\text {th }}$ day of storage. The overall acceptability scores between the treatments were significantly $(\mathrm{p}<0.05)$ higher in peanut flour incorporated curls on day 0 and $14^{\text {th }}$ of the storage as compared to rest of the treatments. The decline in overall acceptability scores could be attributed to changes in scores of colour and appearance, flavour, texture and other sensory attributes. Similar findings have also been reported by Kumar and Sharma (2004), Bhat and Pathak (2009), Bhat et al. (2013a) and Bhat et al. (2013b) for various meat products.

\section{Conclusions}

Fish curls of very good palatability could be prepared by incorporating 20 percent corn flour or 10 percent black gram flour or 10 percent peanut flour in formulation substituting rice flour. Although, flours improved the sensory attributes, both control as well as flour incorporated fish curls could be conveniently packed in LDPE pouches for a period of 21 days in ambient conditions without any marked loss of physicochemical, microbial and sensory quality. Thus, the present study showed successful utilization of different flours and fish in the preparation of curls.

\section{Competing interests}

The authors declare that they have no competing interests.

\section{Authors' contribution}

All the authors i.e. WHR, SK, ZFB and PK designed the study. WHR carried out the research work for various physicochemical, microbiological and sensory parameters. ZFB and SK drafted the manuscript. All authors read and approved the final manuscript.

\section{Author details \\ ${ }^{1}$ Mirah Exports Pvt Ltd, Darabassi, SAS Nagar, Punjab, India. ${ }^{2}$ Division of Livestock Products Technology, Faculty of Veterinary Sciences and Animal Husbandry, Sher-e-Kashmir University of Agricultural Sciences and Technology of Jammu, R S Pura, Jammu, Jammu and Kashmir 181102, India. ${ }^{3}$ Division of Livestock Products Technology, GADVASU, Ludhiana, Punjab 141004, India.}

Received: 21 November 2013 Accepted: 11 February 2014 Published: 21 February 2014

\section{References}

APHA (1984) In: Speck ML (ed) Compendium of methods for the microbiological examination of foods, 2nd edn. American Public Health Association, Washington DC
Banerjee R, Verma AK, Das AK, Rajkumar V, Shewalkar AA, Narkhede HP (2012) Antioxidant effects of broccoli powder extract in goat meat nuggets. Meat Sci 91:179-184

Bhat ZF, Pathak V (2009) Effect of mung bean (vigna radiata) on quality characteristics of oven roasted chicken seekh kababs. Fleischwirtschaft Int 06:58-60

Bhat ZF, Pathak V (2011) Quality evaluation of mutton Harrisa during one week refrigerated storage. J Food Sci Technol 49(5):620-625

Bhat ZF, Pathak V, Bukhari SAA, Ahmad SR, Bhat H (2010) Quality changes in chevon Harrisa (meat based product) during refrigerated storage. Int J Meat Sci 1(1):52-61

Bhat ZF, Pathak V, Bhat HF (2011) Storage studies of chicken seekh kababs extended with different non-meat proteins. Fleischwirtschaft Int 01:87-91

Bhat ZF, Pathak V, Bhat HF (2013a) Effect of refrigerated storage on the quality characteristics of microwave cooked chicken seekh kababs extended with different non-meat proteins. J Food Sci Technol 50(5):926-933

Bhat ZF, Kumar P, Kumar S (2013b) Effect of skin, enrobing and refrigerated storage on the quality characteristics of chicken meat balls. J Food Sci Technol 50(5):890-899

Borch E, Kant-Muermans ML, Blixt Y (1996) Bacterial spoilage of meat and cured meat products. Int J Food Microbiol 33:103-120

Brewer MS, Ikins WG, Harbers CAZ (1992) TBA values, sensory characteristics and volatiles in ground pork during long-term frozen storage: effects of packaging. J Food Sci 57(558-63):580

Chang CC, Yang JH, Chou CK, Tseng T (2010) Effect of replacing pork lard with carrot and onion on the quality of chinese style sausage. J Agric Assoc Taiwan 11(4):374-386

Chidanandaiah, Keshri RC, Sanyal MK (2009) Effect of sodium alginate coating with preservatives on the quality of meat patties during refrigerated storage. J Muscle Foods 20:275-292

Das A, Nath DR, Kumari S, Saha R (2013) Effect of fermented bamboo shoot on the quality and shelf life of nuggets prepared from desi spent hen. Vet World 6(7):419-423

García ML, Dominguez R, Galvez MD, Casas C, Selgas MD (2002) Utilization of cereal and fruit fibres in low fat dry fermented sausages. Meat Sci 60:227-236

Greene BA, Cumuze TH (1982) Relationship between TBA numbers and in experienced panelists assessment of oxidized flavour in cooked beef. J Food Sci 47:52-58

Incze K (1992) Raw fermented and dried meat products. Fleischwirtschaft 72:58-62

Jay JM (1996) Modern food microbiology, 4th edn. CBS Publishers and Distributors, New Delhi, India

Kalra CL, Kaur S, Sharma TC, Kulkarni SC, Berry SK (1987) Studies on the preparation, packaging and storage of potato snacks from clod store potatoes. Indian Food Packer 45:30-39

Kandeepan G, Anjaneyulu ASR, Kondaiah N, Mendiratta SK (2010) Quality of buffalo meat keema at different storage temperature. Afr J Food Sci 4 (6):410-417

Keller JE, Skelley GC, Acton JC (1974) Effect of meat particle size and casing diameter on summer sausage properties during. J Milk Food Technol 37:297-300

Kilinc B (2009) Microbiological, sensory and color changes of anchovy (engraulis encrasicholus) patties during refrigerated storage. J Muscle Foods 20:129-137

Kumar M, Sharma BD (2004) Efficacy of barley flour as fat substitute on processing quality and storage stability of low-fat ground pork patties. J Food Sci Technol 41(5):496-502

Kumar D, Tanwar VK (2011) Effects of incorporation of ground mustard on quality attributes of chicken nuggets. J Food Sci Technol 48(6):759-762

Kumar RR, Sharma BD, KumarM C, Biswas AK (2007) Storage quality and shelf life of vacuum-packaged extended chicken patties. J Muscle Foods 18(30):253-263

Kumar G, Goswami M, Pathak V, Singh VP (2012) Development of chicken sticks by replacement of rice flour with different levels of minced chicken meat. J Food Process Technol 3:10

Modi VK, Mahendrakar NS, Narasimha DR, Sachindra NM (2003) Quality of buffalo meat burger containing legume flours as binders. Meat Sci 66:143-149

Murguerza E, Fista G, Ansorena D, Astiasaran I, Bloukas JB (2002) Effect of fat level and partial replacement of pork backfat with olive oil on processing and quality characteristics of fermented sausages. Meat Sci 61:397-404

Padda GS, Sharma N, Bisht GS (1989) Effect of some vegetative extenders on organoleptic and physico-chemical properties of goat meat balls. Indian J Meat Sci Technol 2:116-122 
Park J, Ghee KS, Kim BK, Rhee KC (1993) High-protein texturized products of defatted soy flour, corn starch and beef: shelf life, physical and sensory properties. J Food Sci 58(1):21-27

Prabhavat S, Hengsawadi D, Lohana T (2000) Production of snacks from composite flour of full fat soy flour and addition of nata de coco. Kasetsart J (Nat Sci) 34:289-299

Prinyawinatkul W, Larry R, Beuchat R, Phillips D, Resurrion AVA (2007) Modeling the effect of peanut flour, feed moisture content and extrusion temperature on the physical properties of extruded snack products. Int J Food Sci Technol 30:37-44

Prinyawiwatkul W, McWatters KH, Beuchat LR, Phillips RD (1997) Physicochemical and sensory properties of chicken nuggets extended with fermented cowpea and peanut flours. J Agri Food Chem 45:1891-1999

Ratanatriwong PA, WongSa-Ngasri W, Suwansri S, Thanasukarn P (2011) Optimization of drying-process efficiency and shelf-life extension by active packaging in crispy minced-fish snacks, The 12th Asean Food Conference. 16-18 June, 2011. BITEC Bangna, Bangkok, Thailand

Sahoo J, Anjaneyulu ASR (1997) Effect of natural antioxidants and vaccum packaging on the quality of buffalo meat nuggets during refrigerated storage. Meat Sci 47:223-230

Seman DL, Moody WG, Fox JD, Gay N (1987) Influence of hot and cold deboning on the palatability, textural and economic traits of restructured beef steaks. J Food Sci 52(879-882):889

Serdarouglu M, Degirmencioglu O (2004) Effect of fat level (5, 10 and 20\%) and corn flour (0,2 and 4\%) on some properties of Turkish type meat balls (koefte). Meat Sci 68(2):291-296

Shaviklo GR, Thorkelsson G, Rafipour F, Sigurgisladottir S (2011) Quality and storage of extruded puffed corn-snacks during 6-month storage at ambient temperature. J Sci Food Agric 91:886-893

Siaw CL, Idrus AZ, Yu SY (1985) Intermediate technology for fish cracker (Keropok) production. J Food Technol 20:17-21

Singh VP, Sanyal MK, Dubey PC, Mendiratta SK (2011) Quality assessment of vacuum packaged chicken snacks stored at room temperature. J Stored Products Postharvest Res 2(6):120-126

Snedecor GW, Cochran WG (1994) Statistical Methods, 8th edn. lowa State University Press, Ames, lowa

Sudheer K, Mandal PK, Das C, Pal UK, Santosh Kumar HT, Rao VK (2011) Development of restructured chicken block utilizing gizzard and its refrigerated storage stability. J Food Sci Technol 48(1):96-101

Suknark K, Phillips RD, Mc Watters KH (1998) Acceptance by American and Asian consumers of extruded fish and peanut snack products. J Food Sci 63(4):721-725

Tarladgis BG, Watts BM, Younathan MT, Dugan L (1960) Rancidity changes in food. J Am Oil Chem Soc 37:44-48

Tettweiler P (1991) Snack foods worldwide. Food Technol 45(2):58

Thakur S, Saxena DC (2000) Formulation of extruded snack food (gum based cereal-pulse blend): optimization of ingredients levels using response surface methodology. Lebenson Wiss Technol 33(5):354-361

Tharanathan RN, Mahadevamma S (2003) Grain legumes-A boon to human nutrition. Trends Food Sci Technol 14:507-518

Witte VC, Krause GF, Bailey ME (1970) A new extraction method for determining 2-thiobarbituric acid value of pork and beef during storage. J Food Sci 35:582-585

doi:10.1186/2193-1801-3-106

Cite this article as: Raja et al.: Effect of ambient storage on the quality characteristics of aerobically packaged fish curls incorporated with different flours. SpringerPlus 2014 3:106

\section{Submit your manuscript to a SpringerOpen ${ }^{\odot}$ journal and benefit from:}

- Convenient online submission

- Rigorous peer review

- Immediate publication on acceptance

- Open access: articles freely available online

- High visibility within the field

- Retaining the copyright to your article

Submit your next manuscript at $\gg$ springeropen.com 